\title{
Church Schools' Reforms in the With-Corona Age: Focusing on Middle and High Schools
}

\author{
Sang Kyu Woo ${ }^{1}$ \\ ${ }^{1}$ Ph.D. Candidate, Department of Education, Kyungpook National University, Republic of Korea, \\ skocdskocd@naver.com
}

\begin{abstract}
In general, the level of trust for Korean churches is not very high. Due to numerous causes, Korean churches are in decline. Furthermore, Korean churches are facing even more difficulties due to the COVID-19. This research is aimed to identify the causes of the churches' decline and provide educational solutions that focus on church schools for middle and high school students. Firstly, in order to recover ethical righteousness, the previous paradigm must be abandoned based on faith alone and accept a balanced religious life that includes love for neighbors. This means abandoning the exclusivity that churches have shown to non-Christians as well. Secondly, rather than relying on the educational talents of the instructors, church schools must adopt an efficient system of education. They must find diverse methods of education rather than a one-way lecture that does not provide opportunity and promote critical thinking. Not only the leader should educate the public, but also small groups should be activated so that students and teachers can interact with each other. Furthermore, students are spending more time with their parents, so parental educations are becoming essential as well. To achieve these goals, some investments are needed in the church schools. Thirdly, some digital education is needed that is appropriate during the pandemic period. Students adapt quickly to digital culture and are very familiar with it. Consequently, instructors must not passively wait for the return to the period before COVID-19 and accept reality. There is a need to interact with students via SNS which they are already familiar with. This research is intended to find the solutions based on previous research results and literal data.
\end{abstract}

Keywords: Christian Education, With-Corona, Small Groups, Church Schools, Middle and Highschool, Education Professionals, Blended Learning, Social Network

\section{Introduction}

Korean churches have had positive influences on society, but the public has condemned the churches for the numerous negative influences they had. In a 2020 survey, $30.7 \%$ of the participants have found Christian voluntary activities most helpful to the Korean community. Among the religions, $28.8 \%$ have replied as Catholic, $13.5 \%$ have answered Buddism, and 2.3\% others. On the other hand, participants responded that the cause of the churches' negative influences was mostly due to improper use of funds, exclusivity shown to other religions, and general lack of concordance between the Christian teachings and their actions. Furthermore, another survey consisting of 1000 participants was conducted where $68 \%$ have answered that Korean preachers were untrustworthy and $65.3 \%$ have shown the same answer for Christians in general. Only 30\% have answered that Korean preachers were worthy of trust, and $32.9 \%$ have answered likewise for Christians in general. Another result of the same survey showed that $61.6 \%$ of the participants saying that the Korean church does not communicate well with the outside

Received: September 10, 2021; $1^{\text {st }}$ Review Result: October 24, 2021; ${ }^{\text {nd }}$ Review Result: December 12, 2021 Accepted: January 29, 2022 
world shows that the communication problem is a serious matter that requires attention. The Korean church must accept these criticisms in order to move forward so as to earn the respect that they once deserved from the public[1].

In addition, the spread of COVID-19 from Wuhan region, China in December 2019 has presented many difficulties to the church. The government encourages the public to meet in small groups so as to minimize the chances of an outbreak. This has made it impossible for the church to congregate and attend sermons. Medical professionals are suggesting that we need to make changes in order to adapt to the with-Corona age.

This research will attempt to find the solution from the church school's perspective. In order to do so, there is a need to consider the history of Korean church schools and the problems they faced in the past as well.

\section{The Current Status of Korean Churches and Church Schools}

\subsection{Korean Churches' Problems and Shortcomings}

Korean churches have shown numerous achievements in the last 130 years. However, during the last 20 years, reports have been received that the churches are not showing any signs of growth. Korean churches continue to participate in volunteer activities, but have not been able to grow and are even showing signs of decline. This is evident in a survey about the social trust of Korean Churches conducted by gi\&com research. This survey was conducted five times in total, in 2008, 2009, 2010, 2013, and 2017. There were a total of 1,000 participants who were chosen in consideration of gender, age, region, religion. The survey was taken in the form of a call interview. The sample population was derived by random sampling in order to maintain its representativeness[1]. An analysis of the survey results is as follows.

Firstly, the general trustworthiness of the church is in dire peril, with two-thirds of the population stating that they do not trust the church. The results have shown similar statistics on all five of the surveys. In [Fig. 1], the public generally does not trust the church.

\section{Church's Trustworthiness}

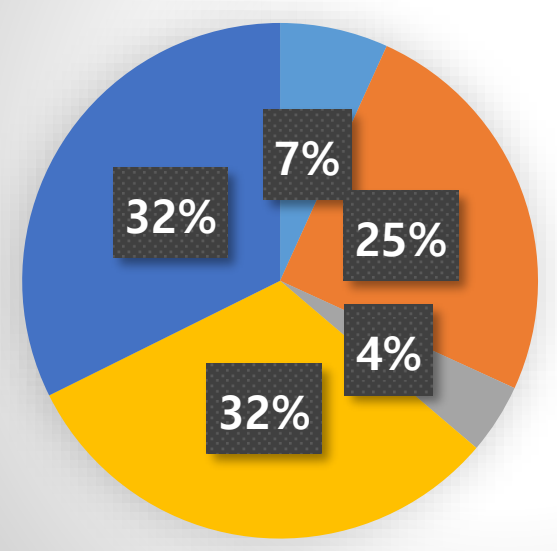

Strongly believe

Believe

Neutral/No answer

Do not believe

Never believe

[Fig. 1] Survey on Church's Trustworthiness Conducted by Christian Ethics Movement 
Secondly, the participants claim that ethics and morality were the key causes of the survey results. A total of $26.6 \%$ of the participants suggested lack of consideration, $23.7 \%$ suggested lack of honesty and $22.7 \%$ wrote exclusivity as the cause of the church's decline. This suggests that the church must show consideration and tolerance toward different religions and that an improvement an improvement on morality also seems necessary. Also, the majority have suggested the church's lack of financial transparency as well [2].

Thirdly, the untrustworthiness that the church has shown in the past is clearly obstructing the church's growth. During the survey, $18.9 \%$ answered that the religion they trusted the most was Christianity, with $26.2 \%$ answering Buddhism and 30\% Catholic. But as time passed, the number of those who trusted the church continued to decline becoming $10.8 \%$ in $2009,8.6 \%$ in $2013,6.9 \%$ in 2017 and dropping to $6.1 \%$ in 2020. Finally, we must note people's positive perceptions about Christian volunteer activities. Participants answered that Christianity was the most enthusiastic about volunteer activities and helping others. After considering such survey results, we may infer that the Korean Church is having difficulties restoring its trust and finding a solution

\subsection{The Decline of Church Schools}

Starting in 2000, the number of students has been decreasing in all church schools, and the percentage of churches that can no longer maintain a church school has escalated to $45-50 \%$. This is relevant to the decrease in a number of believers[3]. For instance, according to the statistics derived from the homepage of The Presbyterian Church of Korea, the total number of church members has been decreasing, while the number of churches has been increasing[4] (see [Table 1]).

[Table 1] Statistics of Church Members for the Last 10 Years By The Presbyterian Church of Korea

\begin{tabular}{|c|c|c|c|c|c|c|c|}
\hline \multicolumn{7}{|c|}{ Statistical change of church members } \\
\hline Year & $\begin{array}{c}\text { Number of } \\
\text { presbyteries }\end{array}$ & $\begin{array}{c}\text { Number of } \\
\text { churches }\end{array}$ & $\begin{array}{c}\text { Number of } \\
\text { pastors }\end{array}$ & $\begin{array}{c}\text { Number of } \\
\text { elders }\end{array}$ & $\begin{array}{c}\text { Number of } \\
\text { staffs }\end{array}$ & $\begin{array}{c}\text { Numberof } \\
\text { believers }\end{array}$ & $\begin{array}{c}\text { Total number } \\
\text { of believers }\end{array}$ \\
\hline 2010 & 64 & 8,162 & 15,751 & 26,999 & 829,850 & $1,695,952$ & $2,852,311$ \\
\hline 2011 & 64 & 8,305 & 16,257 & 27,487 & 833,895 & $1,717,790$ & $2,852,125$ \\
\hline 2012 & 65 & 8,417 & 16,853 & 27,931 & 846,167 & $1,720,872$ & $2,810,531$ \\
\hline 2013 & 65 & 8,592 & 17,468 & 28,886 & 852,165 & $1,734,229$ & $2,808,912$ \\
\hline 2014 & 65 & 8,731 & 18,121 & 29,512 & 876,958 & $1,739,235$ & $2,810,574$ \\
\hline 2015 & 66 & 8,843 & 18,699 & 30,328 & 873,678 & $1,745,305$ & $2,789,102$ \\
\hline 2016 & 67 & 8,984 & 19,067 & 31,237 & 885,856 & $1,733,006$ & $2,730,900$ \\
\hline 2018 & 67 & 9,096 & 19,832 & 31,268 & 871,973 & $1,716,953$ & $2,627,696$ \\
\hline 2019 & 68 & 9,190 & 20,506 & 32,278 & 879,154 & $1,681,506$ & $2,554,227$ \\
\hline 2020 & 68 & 9,288 & 20,775 & 32,511 & 869,830 & $1,674,221$ & $2,506,985$ \\
\hline
\end{tabular}

For the last 10 years, the decline in number of believers reached to approximately 340000 but the number of churches has increased from 8,162 to 9,288. This sudden increase is due to new pioneering churches and the separtion of existing churches, which lead to decreased members per church. There are also some cases in which members leave the church or stop teaching in church schools due to disappointments toward the church. This leads to a lack of staff members necessary to maintain the church schools. [Table 2] shows the gradual decrease regardless of age in the number of church school students that started in 2010 and still continues today. In 2010, the number of elementary students who attended church schools was 18,305 , but was reduced to 15,206 in 2019 , a total reduction of $17 \%$. The 
number of middle and highschool students was reduced from 188,304 to 115,025 , with a total of $39 \%$ in reduction. This difference in ration is assumed to be because unlike elementary school students, middle and highschool students are more expressive in their reluctance to go to church while for elementary school students, their parents may have their children enter church schools regardless of their children's will.

[Table 2] Statistics of Church Schools for the Last 10 Years By The Presbyterian Church of Korea

\begin{tabular}{|c|c|c|c|c|c|c|c|}
\hline \multicolumn{7}{|c|}{ Sunday school's statistical change between 2010 and 2020 } \\
\hline Year & $\begin{array}{c}\text { Infant } \\
\text { school }\end{array}$ & $\begin{array}{c}\text { Toddler } \\
\text { school }\end{array}$ & $\begin{array}{c}\text { Kindergarten } \\
\text { school }\end{array}$ & $\begin{array}{c}\text { Childhood } \\
\text { school }\end{array}$ & $\begin{array}{c}\text { Elementary } \\
\text { school }\end{array}$ & Boy school & $\begin{array}{c}\text { Secondary } \\
\text { school }\end{array}$ \\
\hline 2010 & 18,305 & 24,571 & 67,378 & 64,232 & 74,327 & 89,900 & 188,304 \\
\hline 2011 & 21,429 & 24,130 & 64,731 & 58,419 & 69,015 & 83,266 & 180,308 \\
\hline 2012 & 18,733 & 23,641 & 62,251 & 56,519 & 64,175 & 76,090 & 171,660 \\
\hline 2013 & 17,101 & 21,555 & 58,293 & 50,840 & 59,423 & 68,175 & 157,409 \\
\hline 2014 & 17,523 & 23,323 & 57,649 & 51,112 & 57,880 & 64,637 & 152,327 \\
\hline 2015 & 17,325 & 22,659 & 55,435 & 48,110 & 55,317 & 62,358 & 146,763 \\
\hline 2016 & 16,403 & 22,109 & 52,053 & 46,020 & 54,173 & 56,147 & 134,904 \\
\hline 2018 & 19,088 & 21,604 & 50,412 & 46,493 & 51,803 & 56,256 & 126,235 \\
\hline 2019 & 14,934 & 20,475 & 48,101 & 44,288 & 50,193 & 54,687 & 119,691 \\
\hline 2020 & 15,206 & 19,872 & 45,654 & 43,461 & 48,807 & 52,427 & 115,025 \\
\hline
\end{tabular}

\section{The Cause of the Church Schools' Decline}

\subsection{Reduced Number of Total Fertility and School Age Population}

According to [Table 3], the total population of Korea has been steadily increasing for the last five years. The total population is increasing, but the number of infants has been decreasing[5]. A decrease in total fertility leads to decreased school age population as well.

[Table 3] The Total Number of Infants and Total Fertility (2011-2020) By KOSIS: 2011-2020[5]

\begin{tabular}{|c|c|c|}
\hline Year & Number of infants & Total Fertility \\
\hline 2016 & 406,243 & 1.17 \\
\hline 2017 & 357,771 & 1.05 \\
\hline 2018 & 326,822 & 0.98 \\
\hline 2019 & 302,676 & 0.92 \\
\hline 2020 & 272,337 & 0.84 \\
\hline
\end{tabular}

In [Fig. 2], the number of working age population is expected to decrease from 37,570,000 in 2017 to $17,840,000$ in 2067 , with the ratio decreasing from $73.2 \%$ to $45.4 \%$. In the 2020 s, the estimated reduction is 330,000 , and in $2030,520,000$ per year. The population percentage of those over 65 or older is expected to increase from $13.8 \%$ to $46.5 \%$. In 2025 , the elderly population is expected to be more 
than $10,000,000$ and in 2067,18270000 . The population percentage of children from $0-14$ is expected to decrease from $13.1 \%$ to $8.1 \%$. The total will decrease from $6,720,000$ in 2017 to 5,000,000 in 2030, and 318,0000 in 2,067. The school age population will decrease from $8,460,000$ in 2017 to $3,640,000$ in 2067 as well[5].
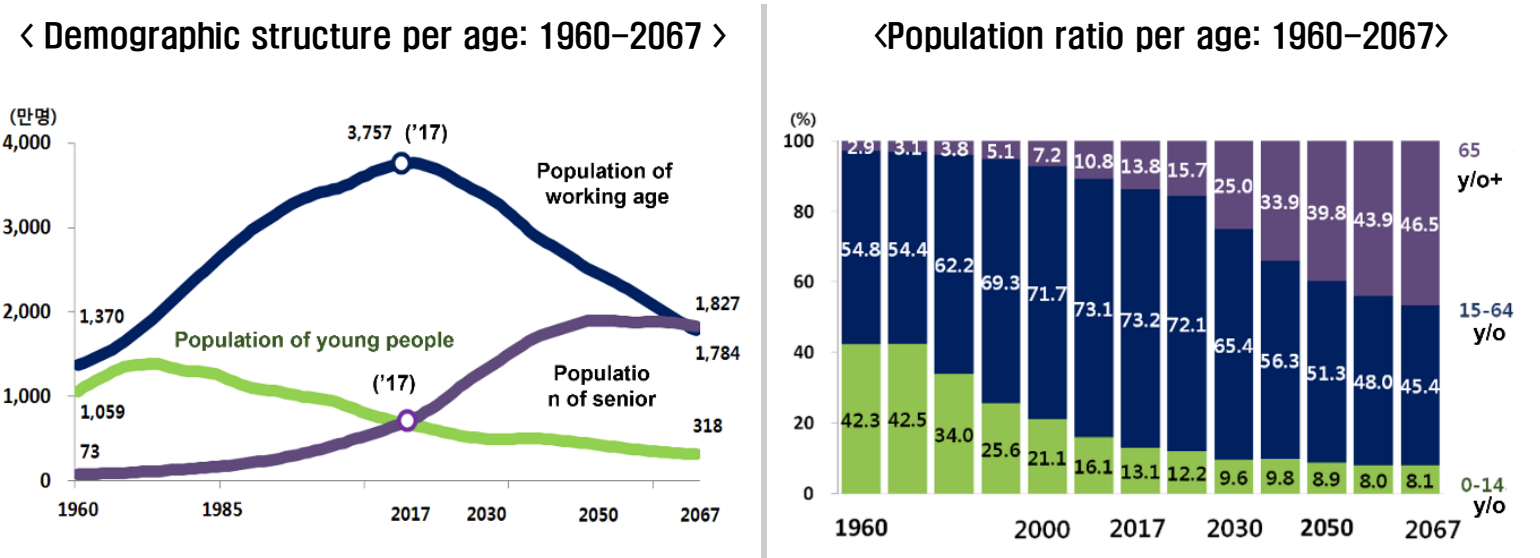

[Fig. 2] Tentative Statistics Results of Birth and Death Rates: Demographics Structure per Age and Population Ratio per Age (1960-2067) by Statistics Korea[5]

[Table 4] shows that the total number of students has been decreasing since 2011 and according to the Ministry of Education, the number of those receiving education have also been decreasing as well[6].

Such a decrease in the number of school age population may have had an impact on the decline of church schools. However, the decrease in middle and highschool students in [Table 4] was 31\% while in church schools, it was 39\%. So there seems to be another cause for the church schools' decline.

[Table 4] Number of Students in Korea By KOSIS[6]

\begin{tabular}{|c|c|c|c|c|c|}
\hline & 2016 & 2017 & 2018 & 2019 & 2020 \\
\hline Kindergarten & 704,138 & 694,631 & 675,998 & 633,913 & 612,538 \\
\hline Elementary & $2,672,843$ & $2,674,227$ & $2,711,385$ & $2,747,219$ & $2,693,716$ \\
\hline Middle school & $1,457,490$ & $1,381,334$ & $1,334,288$ & $1,294,559$ & $1,315,846$ \\
\hline Highschool & $1,752,457$ & $1,669,699$ & $1,538,579$ & $1,411,027$ & $1,337,320$ \\
\hline Junior college & 697,214 & 677,721 & 659,232 & 643,762 & 621,772 \\
\hline University & $2,084,807$ & $2,050,619$ & $2,030,033$ & $2,001,643$ & $1,981,003$ \\
\hline University of Education & 15,903 & 15,839 & 15,788 & 15,697 & 15,628 \\
\hline Graduate school & 332,768 & 326,315 & 322,232 & 319,240 & 320,595 \\
\hline
\end{tabular}

\subsection{Professionalism and Morality of the Church School's Instructors}

In [Fig. 3], 30\% of the participants answered that a preacher's words and actions were trustworthy. This is even less than half of the $68 \%$ of the participants who answered negatively. Also, only $32.9 \%$ answered that Christians were trustworthy, compared to $65.3 \%$ of the participants who answered negatively. The society has high expectations toward the church in terms of morality and ethics. This may be caused by the high standards of the society, but there is much that the church must reflect upon as well. 


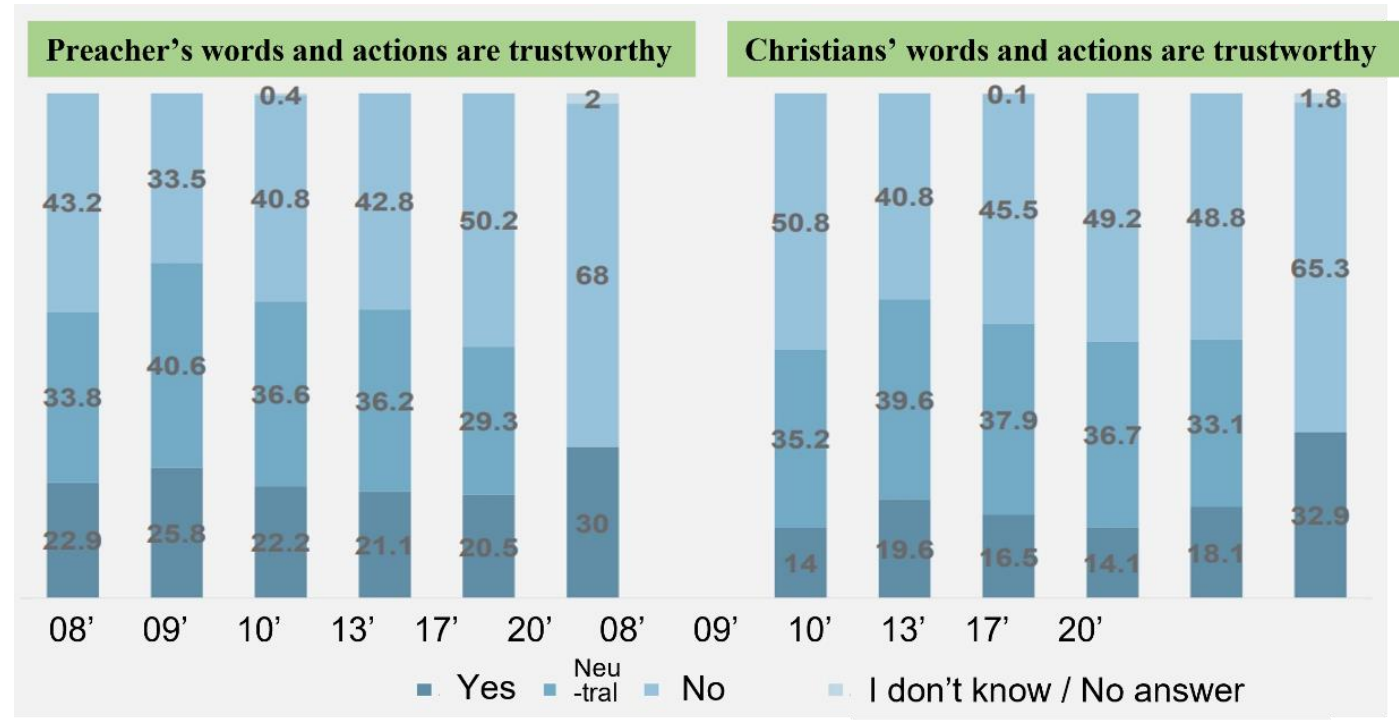

[Fig. 3] Survey on Church's Social Trustworthiness Conducted by Christian Ethics Movement[1]

Participants have also shown great disappointment toward the church for its lack of financial transparency. This problem is presenting itself annually. When asked about the cause of the church schools' decline, experts look to the instructors while teachers and parents point out five days of work per week and church schools' irrelevance to the Korean university entrance examination. Among these, $48.4 \%$ believe that lack of professionalism is the cause and $19.1 \%$ believe that lack of morality is the cause[7]. Also, the entrance exam-oriented educational environment is a factor in not attending church due to supplementary learning. A decrease in the total number of church members leads to a decrease in church school teachers, and as a result, there are cases where they urgently take on the role of teachers without professional education.

\subsection{Church Schools' Slow Adaptation to Digital Education}

Due to the church's conservative tendency, it has taken a long time for the church to accept musical instruments such as drums and guitars. In 2000s, there have been numerous technological advances and the church has also accepted the use of lighting systems and various musical instruments as well. However, digital technology has brought about many changes[8][9]. According to Ted Baehr and Pat Boone, American teenagers spend approximately 800 hours in churches, 2,000 hours with their parents and 11,000 hours in schools before reaching 17. But they also answered that they spend 63,000 hours on social networks. This shows the considerable influence that social network has on teenagers[3].

With the 4th industrial revolution, artificial intelligence, 3D printing, robots and drones may be seen in schools as well[10]. Students interact with people around the world via Youtube, Instagram, Facebook, etc. In 2020, church schools have been heavily influenced by the COVID-19 due to long distance sermons. After two years, the church schools have not been able to find a suitable solution. So this research is going to suggest a few solutions for middle and high schools.

\section{Solutions}

\subsection{A Balanced Religious Life}

In order to solve the problem of morality and ethics, the church school must accept a new paradigm. 
True religion means a vertical relationship with the Lord, and a horizontal relationship with your neighbors. The Korean Church has always been focused on the vertical relationship with the Lord such as a passion for missonaries, charity, etc. This leads to church members acting righteously in the church, but not so in other places. Seymour mentioned that such teachings lead church members to go to churches for the sake of becoming active member rather than for religious reasons[11].

As seen in survey results, the society expects moral actions from the church. They hope that the church may show more tolerance to non-Christians rather than excluding them. Education for middle and high school students in church schools should play an important role in shaping students' moral values as it is an age when students from a mind-set of their own. Since the church has been exclusively teaching about the significance of religious activities in churches, it is time to teach students about practicing these teachings out in real life.

The paradigm from 'Faith oriented' to 'Life oriented' is necessary which may be followed by civic educations[11]. John Wesley, the creator of Methodism referred to this as (Loving God and neighbor). Korean churches must also educate their students so that they become not only members of the church but a member of the society as well.

\subsection{Forming a Systematic Education Policy Rather Than Relying on Individual Talent}

Due to decreased church members, church schools find it difficult to hire professionals as instructors. This leads to a lack of professionalism. Those who stay for long periods rely upon their experience when teaching students. So depending on the instructor's tendency, the direction of focus in which education takes place varies greatly. A systematic educational policy is necessary to avoid such situations.

\subsubsection{Professional Training for Preachers and Instructors}

The cause of the church's decline is due to the lack of passion and professionalism of the leaders[7]. Rather than relying on individual experience and talent, we must resort to professional training and education. During this education, professionals of Bible teachings must be present. A preacher cannot be a master of everything. Other professionals adept at sex education, career education, and so forth must be present in order to meet the new demands of students.

\subsubsection{Diverse Educational Methodology}

Rather than forcing students to memorize knowledge, a new way of education that requires students to actively participate is necessary[12]. There are many ways to garner such participation besides lectures such as workshops, practical sessions, field trips, etc.

\subsubsection{Professional Small Group Education}

A one-way communication whether from a preacher or from an instructor leads to lack of action from the students[10]. Rather than listening to sermons passively, small groups must be formed so that they may discuss the contents of the sermons themselves and learn for themselves.

\subsubsection{Investment in Church Schools}

The church must invest more in church schools so that the schools may reform their method of education and improve themselves. According to research about the perception of educational leaders on Church schools, the majority of the preachers answered that only $5 \%$ of the church's budget is invested on church schools, and $73.6 \%$ of the preachers answered that they were highly interested in church school educations[11]. There is a stark difference in interest and finances. In order to stop the gradual decline of church schools, more funding is essential. 


\subsection{Digital Education Appropriate for With-Corona Age}

According to the 'SNS status quo and its potentials' data from KT economic management institute, Korea has achieved $87 \%$ in terms of SNS use on the first quarter. Korea currently has $35,500,000$ SNS users in 2020. This is a $15.2 \%$ increase from 2019. The reason is that the number of mobile SNS users upsurged $30 \%$. The average age of SNS users shows that there are 2,210,000 teenaged- Facebook users, $1,910,000$ Instagram users and 810000 Twitter users. For those in their twenties, Instagram has $3,860,000$ users and 178 band users[4].

In August, Mobile Index conducted a research about SNS MAU on the national OS. The results showed that the Neighbor band had the most users with 16570000 users. Instagram with 11650000 users, Kakao Story with 9,760,000 users, and so forth. This study also showed that teenagers preferred Facebook, those between 20-39 preferred the Instagram, those in 40s preferred the Band and those in 50 s preferred Kakaostory.

Students are already used to such SNS. Instructors and preachers are less susceptible to such culture because of their conservative tendencies. Rather than relying on the traditional methods, the church school must learn to accept new technology and put it to use in education.

\subsubsection{Blended Learning}

This method is a combination of face-to-face lectures and long-distance courses. Sermons could be transmitted via YouTube. In 2020, the 'newsnjoy' conducted a survey about non-face to face sermons and posted the results on chungeouram ARMC. The survey was conducted online from August 20th to 26th, 2020. A total of 805 people participated with $47 \%$ of the participants answering that they preferred non-face to face sermons because it was in line with social distancing and $34 \%$ answered that such sermons allowed them more free time. Furthermore, $70 \%$ answered that the disadvantages of such sermons were lack of interaction, $27 \%$ mentioned lack of a feast, and $23 \%$ answered the lack of praise for the lord. With some consideration, church schools may find solutions to the lack of interaction[13].

A total of $36 \%$ of the participants also answered that online preaching could lead to lax religious life and a fall from grace. To solve this problem, the church school instructors may discuss the contents of the course with the students via Zoom.

\subsubsection{Change in Educational Programs}

Now we must accept that the With-Corona Age is upon us. Some may believe that returning to the Period before COVID-19 is possible, but it simply delays progress[14]. Whether we like it or not, we must reform the education methods of church schools. Examples include using Kakaotalk apps for attendance and conducting staff meetings via Zoom

\subsubsection{Parent Education}

Nowadays, students spend more time at their homes. The responsibilities of parents have also increased as well, and parents must be responsible for educations related to religion[12]. To do so, the parents must change their perspectives. Today's parents are more concerned about their children's entrance exams rather than religious growth. This is followed by failure to attend sermons during exam weeks. Some blame the parents for the church schools' decline. About $47.2 \%$ have answered that focusing on secular education, and $40.4 \%$ have answered lack of motivation for religious education as a reason for the church school's decline[7]. This means that parents must also change their views on education in order to guide their children on the right path. 


\section{Conclusion}

The purpose of this study is to find a solution for church schools and help them recover during the pandemic period. In order to do so, this research analyzed the current situation, the cause of the church school's decline, and some solutions and reforms.

Firstly, the Korean church must accept reality rather than attempting to return to the period before COVID-19, thus, there is a need to find ways to adapt to it. In the past, the church has been the driving force in building educational institutes and hospitals and leading the society to the right path, However, the church now finds it difficult to even follow the innovations and changes in the society. Also, church school's officials must find a new way of education that allows students to communicate among themselves so that they may think for themselves.

Secondly, the church must abandon its exclusivity and show tolerance. Rather than teaching about religion, Christians must put such learning into action so that students grow to become not only a member of the church but also a member of the society. In order to do so, the church must change its paradigm so that the church does not focus on simply increasing the number of believers and focus on helping the students grow.

Lastly, the church must invest more in their schools and find professionals as staff members. The church school must create a new systematic education policy. Also, it is important to consider that parents' responsibility has also increased, thus, the parents must show support for the children and the church schools' reforms.

\section{References}

[1] 2020's Social Trust Survey of the Korean Churches Seminar, The Christian Ethics Movement of Korea, pp.11-36, (2020)

[2] Y. J. Ham,B. C. Jun, S. B. Shin, H. C. Lee, C. H. Cho, A Study of Church Ministers' Recognition on Church Education, Bible and Theology, (2015), Vol.75, No.1, pp.1-33, DOI: 10.17156/BT.75.01

[3] H. S. Chang, Strategies of Restoring Church Education in Korea Focused on Children and Youth Education, Bible and Theology, (2015), Vol.75, pp.259-283, DOI: http://dx.doi.org/10.17156/BT.75.09

[4] https://biz.chosun.com/site/data/html_dir/2020/09/07/2020090700514.html, Sep 7 (2020)

[5] http://kostat.go.kr/portal/korea/kor_nw/1/1/index.board?bmode=read\&aSeq=388265, Feb 24 (2021)

[6]https://kosis.kr/statisticsList/statisticsListIndex.do?menuId=M_01_01\&vwcd=MT_ZTITLE\&parmTabId=M_01_01\& outLink=Y\&parentId=A.1;A_6.2;\#A_6.2, Sep 5 (2021)

[7] K. H. Yang, Church Schools’ Diagnosis, Decline, and Revival, Qumran, pp.74-86, (2008)

[8] S. Y. Bai, Media Use and Education of Digital Native, Convergence measures between youth crisis and culture, Proceeding of 2014 Spring Conference, Korean Society for Christian Education \& Information Technology, pp.15-31, (2014), May 24, Korea.

[9] J. D. Yu, Church Education in the COVID-19 Era, Journal of Christian Education in Korea, (2020), No.63, pp.13-37, DOI: http://dx.doi.org/10.17968/jcek.2020..63.001

[10] K. M. Jung, Mission in the Fourth Industrial Revolution, Theology of Mission, (2017), No.48, pp.265-294, DOI: http://dx.doi.org/10.14493/ksoms.2017.4.265

[11] S. J. Yang, A Study on the Disciplecitizenship for Adolescent Faith and Humanity Education: Focused on John Wesley's Educational Ministry, Journal of Christian Education in Korea, (2019), Vol.58, No.2, pp.53-78, DOI: http://dx.doi.org/10.17968/jcek.2019..58.002 
[12] Sang Jin Park, A Christian Understanding of the College Entrance Examination, Journal of Christian Education in Korea, (2008), No.18, pp.99-129, DOI: http://dx.doi.org/10.17968/jcek.2008..18.004

[13] https://www.newsnjoy.or.kr/news/articleView.html?idxno=301312, Sep 4 (2020)

[14] J. K. Choi, Tasks of Church Education in Uncontacted Environment, Christian Education \& Information Technology, (2020), No.67, pp.227-247 